DOI 10.14746/ssp.2016.3.2

Magdalena MusiaŁ-KARG

Adam Mickiewicz University in Poznań

\title{
The Role of National Referendum in Central and Eastern European Countries. Selected Experiences ${ }^{1}$
}

\begin{abstract}
Direct democratic choices have been of great importance in Central and Eastern European countries since they have marked the key steps on those states' paths to democracy. Direct democracy - particularly referenda - is arousing increasing interest among politicians and the electorate, which is manifested in the ongoing public debate on the role of civil participation in decision-making processes, as well as in the increase in the number of national referenda held in Europe and worldwide. Hence, studies on referenda in Central and Eastern Europe seem to be a very interesting and academically important task worthy of further exploration. The main research aim of this paper is to answer the question of the role of nationwide referenda in the political practice of Central and Eastern European states, as well as the question of the future prospects for the use of referenda. More emphasis is placed on referenda conducted after 1989. On the basis of these research results, referenda are divided into three categories: independence referenda, so called "deepening" referenda and accession referenda.
\end{abstract}

Key words: referendum, direct democracy, Central and Eastern Europe

\section{Introduction}

Democratic government and the choices made by citizens in elections and referendums determine the paths democratic states take in shaping their policies. Direct democracy as a form of democratic ruling concedes to all citizens the right to decisive voting on political issues and therefore comes as close as possible to the principle of political equality (Schiller, 2003). Without any doubt 'direct' choices have been of great importance in Central and Eastern European countries since they have marked the key

1 This article has been written within the research project: Demokracja bezpośrednia w Europie Środkowej i Wschodniej po 1989 roku: wymiar formalnoprawny i praktyczny. Analiza politologiczna (UMO-2014/15/B/HS5/01866) financed by the National Science Center in Poland. 
steps on those states' paths to democracy. From this perspective, the concept of civil participation in the process of making decisions (Kishna, 2001, p. 3) related to the state has been a significant element of European history, which became particularly important in the context of political transition in Central and Eastern Europe at the turn of the 1980s.

Direct democracy instruments seem to play today an increasingly important role across the globe in involving citizens in the political process. The phenomenon of referendum is an important part of the political processes in many European countries. Many authors point out that in democratic states the referendum and other direct instruments should not be thrown away since they are crucial devices of citizens' government. The issue of direct democracy and its institutions has been drawing the attention of researchers worldwide for a long time, whereas recent years clearly evidence an increased interest in direct forms of democracy in Europe. Whether in Western Europe, where democracy has long been well established, or in the states of the former Soviet bloc, direct democracy supplements representative governance (Linder, 1996, p. 26; Barber, 1984, pp. 179-180) as evidenced by numerous referenda held on varied occasions in the west, center and east of Europe. Observers who represent such entities as the Initiative and Referendum Institute - Europe, Democracy International, IDEA - International Institute for Democracy and Electoral Assistance, other NGOs and think tanks agree that out of the many instruments of direct democracy the importance of referenda has been on the rise, as evidenced by the large number of referenda conducted over the last 20-25 years. This is likely to have resulted from the fact that direct democracy was initially 'triggered' by the political transition in the states of the former Soviet bloc and then reinforced by the process of European integration, which facilitated more frequent appeals to public opinion by means of national referenda than before. The referenda held in Central and Eastern Europe at that time were of particular importance, as in many cases they were of symbolic significance (independence and accession to the European Union). This text discusses the experiences of holding referenda in Central and Eastern Europe. The primary research goal is to answer the question of the role of national referenda in Central and Eastern Europe, thereby indicating the similarities and differences in the political practice of different states in this part of the continent, on the one hand, and answering the question of the future prospects of this form of governance. The theoretical aspects of considerations herein are primarily based on the findings of such foreign scholars as Ian Budge 
(1996), Thomas E. Cronin (1989), Lawrence LeDuc (2003), Matt Qvortrup (2002) and Markku Suksi (1993).

The empirical part refers mainly to statistics (on the number, time, topic and results of referenda) which have turned out to be exceptionally helpful when analyzing the use of state referenda in Central and Eastern Europe, and allowed me to compare the results of studies. This paper concentrates on examining the number of popular votes ${ }^{2}$ held in this part of Europe, determining their character (whether they were voluntary or mandatory) as well as the topic of each. Referenda held in 24 countries $^{3}$ in Central and Eastern Europe from January 1, 1900 to October 31, 2016 are analyzed. ${ }^{4}$ Approaching the topic in this manner made it possible to examine how the instrument of the referendum was used in individual countries throughout an entire century (thereby identifying the states with the greatest experience of referenda) and determine the periods when referenda were most frequently used in decision-making processes in different countries. The analysis of the topics the referenda addressed made it possible to indicate the themes that are typically subjected to a vote. This paper is not an exhaustive analysis of how the instrument of the referendum has been used in the part of Europe concerned, and it intends to make a contribution to further discussion on how this instrument may be used in the future and how efficient it is.

\section{Referenda in Central and Eastern Europe}

The analysis of how referenda are used in practice in Europe in order to solve different politically and socially significant issues makes

${ }^{2}$ It should be noted that different authors quote different numbers of referenda held in different countries. These differences are mainly caused by the fact that numerous scholars treat each question asked in a referendum as a separate referendum. This practice is most popular among Anglo-Saxon scholars. In Polish literature, by turn, a referendum where voters answer several questions is treated as a single referendum. This approach is adopted in the present paper - which referenda addressed several different issues and encompassed several questions is indicated. Nevertheless, such votes are treated as a single referendum, since they were held simultaneously.

${ }^{3}$ Albania, Belarus, Bulgaria, Bosnia and Hercegovina, Croatia, Cyprus, Czech Republic (Czechia), Estonia, Hungary, Kosovo, Latvia, Lithuania, Macedonia, Malta, Moldova, Montenegro, Poland, Romania, Russia, Serbia, Slovakia, Slovenia, Turkey, Ukraine.

${ }^{4}$ Former version of this paper was published in: Musiał-Karg, 2012. This paper is a reference and continuation (and complement) of considerations on the role of referendum institution in Central Eastern Europe. The research has been updated to 2016. 
it possible to conclude that this instrument enjoys considerable interest in the electorate. ${ }^{5}$ Its popularity may be evidenced by the number of votes held as well as the high average voter turnout. Both in Western Europe and Central and Eastern Europe an average of more than $60 \%$ of voters have taken part in all referenda held since the beginning of 1900. It should be noted, however, that civil participation in the election processes in Central and Eastern Europe raises considerable concerns. The studies of referenda held in what are called 'young democracies' evidence that the highest turnout was recorded when the matters of regaining independence and accessing the European Union were being decided. The results of the independence referenda were quite predictable and there were no concerns about the turnout. Yet the turnout in later referenda was considerably lower. What's more due to the low participation rate some referenda has been invalidated. For instance, in Hungary in October $2016,{ }^{6}$ only $40.4 \%$ cast valid ballots - short of the required 50\% threshold, or in Poland in September 2015, ${ }^{7}$ only 7.8 percent of voters took part in three-question referendum, way below the $50 \%$ threshold.

When analyzing referenda held in Europe, a considerable difference can be noted as to the time when referenda started to be used in both parts of the continent. In Western Europe referenda were conducted from the very beginning of the $20^{\text {th }}$ century and their number grew considerably af-

${ }^{5}$ For more on this topic see the works by M. Musiał-Karg, E. Zieliński, M. Gallagher, M. Marczewska-Rytko, E. Kużelewska, B. Kaufmann and others.

${ }^{6}$ In February 2016, the Hungarian government decided to hold a national referendum on the EU mandatory distribution system of refugees among the Member States. The government proposed the following referendum question: "Do you want the European Union to be able to require the resettlement of non-Hungarian citizens in the country without the Hungarian parliament's approval?" The question was approved both by the National Election Committee and - after rejecting four complaints from opposition parties - the Supreme Court of Hungary. According to Hungarian regulations, the vote to be valid and binding required the turnout higher than $50 \%$.

7 The nationwide referendum consisted of three questions: 1. Are you in favor of introducing single-member constituencies in elections to the Sejm of the Republic of Poland? 2. Are you in favor of maintaining the current system of financing political parties from the state budget? 3. Are you in favor of introducing a general principle whereby any legal doubts in interpreting tax law would be resolved in favor of taxpayers? All three questions raised problems in relation to an unconstitutional nature of the first question, lack of precision of the second question, and irrelevance of the third question. The referendum to be binding required $\min .50 \%$ turnout. 
ter World War II. ${ }^{8}$ There was not a single referendum held in Central and Eastern Europe before 1922, and it was rather rare there in later years as well. Typically, one referendum would be held in only one of those countries in any given year. It should be noted that voter turnout at that time was very high, which was most likely the outcome of the political situation in those countries (e.g. Poland -1946, Romania - 1938, 1941 and 1986, Bulgaria - 1922, 1946 and 1971) or its mandatory character (e.g. Turkey in 1982, when failing to vote could be punished by the loss of voting rights for 5 years). The period of political transition turned out to mark a watershed in referendum practice in Central and Eastern European states, where representative governance was complemented with the elements of direct democracy. The most frequent topics put to the vote at that time concerned regaining independence by the nations earlier encompassed by the communist bloc. The analysis of the number of referenda held shows that referenda enjoyed exceptional interest in this part of Europe in 1992 and 2003, when 8 and 12 referenda were held respectively.

Despite the experience gathered with respect to referenda during the first decades of the $20^{\text {th }}$ century (although this experience was typically not related to democratic governance), 1989 marked a turning point in the use of this form of governance in Central and Eastern European states. As mentioned before, this was the beginning of the political transition aimed at the implementation of a democratic order in the states that had been separated from the (democratic) West by the 'iron curtain.' A total of 86 referenda were held in this part of Europe from January 1989 to October 2016. In terms of topics, over a dozen referenda were held on the issue of regaining independence. In many countries, these popular votes turned out to be the most important referenda ever held, since the decisions made on their basis marked the onset of a democratic transformation. Political, social and economic changes were preceded by the adoption of new constitutions in the respective states, which in many cases were also subjected to referenda. In the 1990s, numerous reforms, for instance privatization-related reforms, were also implemented using this tool of direct democracy. This clearly demonstrated the fact that nationwide referenda were assigned an important role in shaping the political system of the new states - former satellites of the Soviet Union. The increased importance

${ }^{8}$ Centre for Research on Direct Democracy (c2d), http://www.c2d.ch/, October 15, 2016; Musiał-Karg, 2008, p. 186. 
of voting was further confirmed in the referenda on accession to the European Union held in 2003 and later, for instance in Croatia - in 2012.

\section{Referenda on regaining independence}

There is no doubt that referenda on independence were a significant form of democracy in the process of political changes in the countries of the former Soviet bloc. In many of them, referenda on regaining independence marked the beginning of political and social transition. It should be noted here that a vote on independence is about obtaining the legitimate confirmation of the nation's desire to change its political status. Although the results of such votes typically are not binding, after the nation expresses its desire, the government tends to make decisions taking this opinion into account.

The referenda held in Central and Eastern Europe in the early 1990s usually concerned the change of the status of associated territories to that of sovereign states, and adopting the status of a sovereign state by autonomous territories. Therefore, it seems justified to claim that the referendum was a tool applied by societies in the Soviet bloc to express their desire to change the political system and abandon the socialist tradition.

The first referendum on independence was held in Slovenia on December 23, 1990. This was the first referendum there ever" (Lukšic, Kurnik, 2001, p. 192). The referendum in Slovenia started a wave of successive independence votes in Central and Eastern Europe.

Table 1

Referenda on independence in Central and Eastern Europe

\begin{tabular}{||c|c|c|c|c|c|c||}
\hline \multicolumn{1}{|c|}{ State } & Date & Topic & Turnout (\%) & Yes (\%) & No (\%) & Result \\
\hline 1 & 2 & 3 & 4 & 5 & 6 & 7 \\
\hline Slovenia & Dec. 23, 1990 & - independence & 93.31 & 95.71 & 4.29 & accepted \\
\hline Lithuania & Feb. 9, 1991 & - independence & 84.74 & 93.24 & 6.76 & accepted \\
\hline Estonia & Mar. 3, 1991 & - independence & 82.96 & 78.41 & 21.57 & accepted \\
\hline
\end{tabular}

9 Igor Lukšic and Andrej Kurnik claim that the first Slovenian experience in terms of referendum dates back to 1919. This traumatic experience, to quote the authors, took place after World War I ended, and Slovenians joined the kingdom of Serbs, Croats and Slovenians. A referendum was held then to determine the border between Austria and the territories inhabited by both Austrian and Slovenian populations. It was decided in the referendum that the territory would belong to Austria (Lukšic, Kurnik, 2012, p. 192). 


\begin{tabular}{||l|c|c|c|c|c|c||}
\hline \multicolumn{1}{|c|}{1} & 2 & \multicolumn{1}{c|}{3} & 4 & 5 & 6 & 7 \\
\hline Latvia & Mar. 3, 1991 & - independence & 87.56 & 74.90 & 25.10 & accepted \\
\hline Ukraine & Mar. 17, 1991 & $\begin{array}{l}\text { - sovereignty of } \\
\text { Ukraine }\end{array}$ & 83.50 & 83.50 & 16.50 & accepted \\
\hline Croatia & May 19, 1991 & $\begin{array}{l}\text { - independence } \\
- \text { remaining in } \\
\text { Yugoslavia }\end{array}$ & 84.94 & 93.24 & 6.76 & accepted \\
\hline Macedonia & Sept. 8, 1991 & - independence & 71.85 & 95.09 & 4.91 & accepted \\
\hline Ukraine & Dec. 1, 1991 & - independence & 84.18 & 92.26 & 7.74 & accepted \\
\hline $\begin{array}{l}\text { Bosnia and } \\
\text { Herzegovina }\end{array}$ & Mar. 1, 1992 & - independence & 62.45 & 99.69 & 0.31 & accepted \\
\hline Moldova & Mar. 6, 1994 & - independence & 75.10 & 95.40 & 2.00 & accepted \\
\hline Montenegro & May 21, 2006 & - independence & 86.49 & 55.49 & 44.51 & accepted \\
\hline \hline
\end{tabular}

Source: Centre for Research on Direct Democracy (c2d), http://www.c2d.ch/, 15.10.2016.

Further referenda on independence were held in February and March 1991 in four Soviet republics. Despite protests by the USSR authorities, independence referenda were held in Lithuania, Estonia and Latvia, whereas Ukraine held a referendum on sovereignty. In all four instances, over $80 \%$ of voters went to the polls and their definite majority approved of the proposed changes. Another referendum followed in Ukraine in December 1991, this time the topic was regaining independence. The same year, two more votes on the same topic were held in Croatia and Macedonia, followed by Bosnia and Herzegovina in March 1992 and Moldova in March 1994. After this wave of independence referenda, a twelve-year break followed. Another vote on independence, so far the last, was held in Montenegro in May 2006, which resulted in Montenegro separating from Serbia.

The high voter turnout in independence referenda evidenced the high mobilization of societies in respective countries. Civil participation in all these referenda ranged from ca. $62 \%$ to over $90 \%$. This high turnout was accompanied by an unambiguous attitude of voters. In ten out of eleven referenda affirmative answers ("yes") accounted for over $70 \%$ of votes and over $90 \%$ in seven countries. The results of the last vote are an exception in this series of independence referenda, as $55 \%$ of voters voted for independence.

Another characteristic of these independence referenda was a domino effect. The referenda were held over a short period of time (one after another) and therefore the result of a referendum in one country had an impact on the results of successive votes held in other countries later on. 
The experiences gathered in the field of independence referenda constitute a significant contribution to the discussion on the importance of direct democracy in Central and Eastern Europe. The analysis of independence referenda leads to a conclusion that all these referenda were unanimously answered by the electorate, thereby dramatically changing the political map of the world, establishing over a dozen new states in Europe.

\section{Referenda deepening reforms (reforming referenda)}

Another category of referenda conducted in Central and Eastern European states after 1990 can be classified as "deepening" referenda. This name stresses the fact that the referenda that followed the votes on independence held in Central and Eastern Europe aimed to reinforce and deepen the changes initiated at the turn of the 1980s. This category encompasses referenda on new constitutions, first and foremost, referenda on political systems, such as that of parliamentary or presidential elections, and votes on reforms, for instance of privatization or insurance systems.

The majority of "deepening" referenda were held in the 1990s. However, the constitutional referendum held in Serbia in October 2006, five months after the independence vote in Montenegro, also falls into this category. Table 2 presents statistics concerning the "deepening" referenda.

Table 2

Selected "deepening" referenda in Central and Eastern European states

\begin{tabular}{|c|c|c|c|c|c|}
\hline State & Date & Topic & $\begin{array}{c}\text { Turnout } \\
(\%)\end{array}$ & $\begin{array}{l}\text { Yes } \\
(\%)\end{array}$ & Result \\
\hline 1 & 2 & 3 & 4 & 5 & 6 \\
\hline Hungary & $\begin{array}{c}\text { Oct. 26, } \\
1989\end{array}$ & $\begin{array}{l}\text { - presidential elections } \\
- \text { dissolution of workers' militia } \\
\text { - account of the property of the socialist } \\
\text { party } \\
\text { - banning of the socialist party from } \\
\text { workplaces }\end{array}$ & 58.04 & $\begin{array}{l}50.07 \\
94.93 \\
95.37 \\
95.14\end{array}$ & $\begin{array}{l}\text { accepted } \\
\text { accepted } \\
\text { accepted } \\
\text { accepted }\end{array}$ \\
\hline Romania & $\begin{array}{c}\text { Dec. 12, } \\
1991\end{array}$ & - constitution & 67.25 & 79.11 & accepted \\
\hline Lithuania & $\begin{array}{c}\text { June 14, } \\
1992\end{array}$ & $\begin{array}{l}\text { - unconditional withdrawal of the So- } \\
\text { viet troops }\end{array}$ & 76.05 & 92.27 & accepted \\
\hline
\end{tabular}




\begin{tabular}{|c|c|c|c|c|c|}
\hline 1 & 2 & 3 & 4 & 5 & 6 \\
\hline Estonia & $\begin{array}{c}\text { June 28, } \\
1992\end{array}$ & - constitution & 66.76 & 92.00 & accepted \\
\hline Lithuania & $\begin{array}{c}\text { Oct. 25, } \\
1992\end{array}$ & - constitution & 75.26 & 78.23 & accepted \\
\hline Lithuania & $\begin{array}{c}\text { Aug. 27, } \\
1994\end{array}$ & - privatization (8 questions) & 36.89 & $\begin{array}{c}\mathrm{Ca} . \\
89\end{array}$ & invalid \\
\hline Slovakia & $\begin{array}{c}\text { Oct. 22, } \\
1994\end{array}$ & $\begin{array}{l}\text { - disclosure of privatization transac- } \\
\text { tions }\end{array}$ & 19.98 & 93.64 & invalid \\
\hline Slovenia & $\begin{array}{c}\text { Dec. } 8 \\
1996\end{array}$ & $\begin{array}{l}\text { - system of parliamentary elections } \\
\text { (3 proposals): } \\
\text { A. proportionate election } \\
\text { B. German model } \\
\text { C. French model }\end{array}$ & 37.94 & $\begin{array}{l}14.38 \\
44.52 \\
26.19\end{array}$ & $\begin{array}{c}\text { all pro- } \\
\text { posals } \\
\text { rejected }\end{array}$ \\
\hline Poland & $\begin{array}{c}\text { Feb. 18, } \\
1996\end{array}$ & $\begin{array}{l}\text { - general property enfranchisement of } \\
\text { citizens } \\
\text { - liabilities to pensioners and public } \\
\text { sector employees paid from the priva- } \\
\text { tization of public assets } \\
\text { - contribution to the common pension } \\
\text { fund to be made from a portion of pri- } \\
\text { vatized assets } \\
\text { - increased National Investment Fund } \\
\text { share certificates } \\
\text { - privatization vouchers in the property } \\
\text { enfranchisement program }\end{array}$ & $\begin{array}{l}32.44 \\
32.44 \\
32.44\end{array}$ & $\begin{array}{l}94.54 \\
92.89 \\
93.70 \\
21.86 \\
88.30\end{array}$ & invalid \\
\hline Poland & $\begin{array}{l}\text { Apr. 27, } \\
1997\end{array}$ & - constitution & 42.86 & 52.70 & accepted \\
\hline Slovakia & $\begin{array}{c}\text { Sept. 26, } \\
1998\end{array}$ & $\begin{array}{l}\text { - refraining from privatizing enterprises } \\
\text { of strategic importance }\end{array}$ & 44.06 & 84.30 & invalid \\
\hline Serbia & $\begin{array}{l}\text { Oct. } 29, \\
2006\end{array}$ & - constitution & 55.00 & 53.00 & accepted \\
\hline
\end{tabular}

Source: Centre for Research on Direct Democracy (c2d), http://www.c2d.ch/, 15.10.2016.

The analysis of this referendum category points to a conclusion that "deepening" referenda concerned a relatively broad range of issues from the constitution to political issues (Rytel-Warzocha, 2011, pp. 254-255), to the withdrawal of Soviet troops, to privatization issues (Gebethner, 2001). The referenda conducted in this period did not produce the domino effect observable in the case of independence votes.

The most prominent feature of "deepening" referenda was the considerably lower turnout than in the case of independence referenda. Whereas 
participation in the latter exceeded even $90 \%$, the latter were characterized by lower turnouts, as little as $30-40 \%$, resulting in some referenda failing to meet the conditions for validity.

Another significant property of "deepening" referenda was that social support for the proposed changes was considerably lower. The attitudes of voters were not as unanimous as in the case of independence referenda, where in the majority of cases over $90 \%$ of the electorate gave an affirmative answer to the referendum question. In the "deepening" referenda, the supporters of proposed changes ranged from ca. $20 \%$ (as in the 1992 referendum in Poland) to over 90\% (the 1989 referendum in Hungary, the 1992 referendum in Lithuania and the 1994 one in Slovakia, and so on).

"Deepening" referenda can be approached as evidence that after the initial enthusiasm triggered by the onset of political transition, positive emotions subside and the social commitment to matters of apparently less symbolic character - goes down.

\section{Referenda on accession to the European Union}

The referenda on accession to the European Union held in 2003 (and in Croatia in 2011), in relation to the greatest enlargement of the EU, were instrumental in the process of democratic transition in Central and Eastern Europe.

Joining the European Union was perceived as symbolically joining the Western democracies, and was among the priorities of foreign policies of the former members of the Soviet bloc following their political transformation (Kużelewska, 2006). Joining the EU was therefore treated as a matter of general significance, not identified with individual interests but related to the future of all citizens and generations to come. It should be noted that the accession referenda in respective countries were distinguished by uniqueness, and their results - by historical irreversibility. Therefore, turnout was forecast to be high, and social support for individual countries joining the Community was expected to be at a high level as well (Musiał-Karg, 2008, p. 287; Musiał-Karg, 2012, p. 212).

As concerns the 2003 referenda in the countries expected to join EU structures in 2004, Cyprus was the only country not planning to vote. Nine referenda were held from March to September 2003. 
Accession referenda in Central and Eastern Europe

\begin{tabular}{||l|c|l|c|c|c|c||}
\hline \multicolumn{1}{|c|}{ State } & Date & Topic & $\begin{array}{c}\text { Turnout } \\
(\mathbf{\%})\end{array}$ & $\begin{array}{c}\text { Yes } \\
(\mathbf{\%})\end{array}$ & $\begin{array}{c}\text { No } \\
\mathbf{( \% )}\end{array}$ & Result \\
\hline Malta & Mar. 8, 2003 & - joining the EU & 90.85 & 53.65 & 43.65 & accepted \\
\hline Slovenia & Mar. 23, 2003 & - joining the EU & 60.43 & 89.64 & 10.36 & accepted \\
\hline Hungary & Apr. 12, 2003 & - joining the EU & 45.63 & 83.76 & 16.24 & accepted \\
\hline Lithuania & May10-11, 2003 & - joining the EU & 63.30 & 89.93 & 10.07 & accepted \\
\hline Slovakia & May 16-17, 2003 & - joining the EU & 52.15 & 92.46 & 6.20 & accepted \\
\hline Poland & Jun. 07-08, 2003 & - joining the EU & 58.85 & 77.45 & 22.55 & accepted \\
\hline Czech Republic & Jun. 13-14, 2003 & - joining the EU & 55.21 & 72.33 & 23.71 & accepted \\
\hline Estonia & Sept. 14, 2003 & - joining the EU & 64.06 & 66.83 & 33.17 & accepted \\
\hline Latvia & Sept. 20, 2003 & - joining the EU & 73.12 & 67.48 & 32.52 & accepted \\
\hline Croatia & Jan. 22, 2012 & - joining the EU & 43.51 & 66.27 & 33.13 & accepted \\
\hline
\end{tabular}

Source: Kaufmann, 2004, p. 9; Ten referenda on Europe in Europe, 2003; Centre for Research on Direct Democracy (c2d); Musiał-Karg, 2008, pp. 284-294; Musiał-Karg, 2012, p. 204; Podolak, 2014, p. 294.

The voters in all these referenda unambiguously supported membership of the EU, as over $50 \%$ of voters supported accession in every country, and in countries with a minimum turnout requirement for a referendum to be valid (Lithuania, Slovakia, Poland, ${ }^{10}$ Latvia $^{11}$ and Hungary ${ }^{12}$ ) this condition was fulfilled.

The turnout in all the countries concerned exceeded 50\%, but the authorities in many countries were aware that it would be relatively difficult to achieve the threshold required for a referendum to be valid. In order to reduce the risk that the turnout might be too low, Lithuania, Poland, Slovakia and the Czech Republic decided to extend voting time. The referenda organized in these countries were two days long, in the hope that an additional election day would boost turnout. ${ }^{13}$

${ }^{10}$ In Lithuania, Slovakia and Poland a referendum is valid provided that at least half of eligible citizens cast their vote.

11 For the referendum to be valid at least ca. 497,000 voters $(35.14 \%$ of eligible citizens) had to cast their vote, that is at least half of those who voted in the last parliamentary elections (Dziewulski, Otachel, 2003, p. 59).

12 In conformity with Hungarian law, the result of a referendum is deemed valid if the number of answers to one of the questions asked in this referendum ("Yes" or "No") gets more than $25 \%$ of eligible votes.

13 These concerns turned out to be justified, as evidenced by the referenda. During two day referenda the turnout was expected to exceed $60 \%$, whereas in Slovakia it was $52.2 \%$ and in Poland $58.85 \%$. 
All the accession referenda brought a positive result, and on May 1, 2004 eight post-communist countries became EU members. Joining the states of the Old Union meant for them the total abandonment and separation from the former political system, and the symbolic closure of the period named 'post-communism.'

After 2003, Croatia was the only new EU member (alongside Bulgaria and Romania) that decided to carry out a general vote on the issue. The vote in Croatia was held during a financial crisis, the atmosphere was filled with fears, and the election turnout was the lowest of all accession referenda in Central and Eastern Europe.

Concluding these considerations on referenda on accession to the EU, it can be noted that in their case (as evidenced in 2003) the order of votes held in candidate countries was essential. Varied degrees of support made it possible to influence voter preferences by means of the above-mentioned domino effect. ${ }^{14}$ It should be stressed that although the referenda were extended in several countries, the results after the first voting day were far from being as enthusiastic as expected (for instance, after the first day, the turnout in Lithuania was $23 \%$ and together with the votes cast by mail it slightly exceeded $30 \%$; in Poland it was ca. 17\%).

Summing up, the accession votes held in 2003 and 2012 were crucial for future member states from Central and Eastern Europe since they marked a 'symbolic closure of their relation with the former Soviet bloc' and were the final step in doing so. Additionally, in the majority of countries, accession referenda were the first common votes on a strictly 'European issue.'

\section{Conclusions}

The analysis of the experiences of Eastern and Central European states leads to a number of conclusions.

Firstly, the instrument of referendum has been relatively frequently applied to resolve essential political issues - especially over the last two

14 Malta was somewhat exceptional among the states going to vote in 2003, being the first country to hold a referendum despite low civil support and the uncertain results of the vote. Although the referendum was purely advisory in nature, from the point of view of the remaining countries, its outcome was significant for the results of the votes to come there. A Maltese "No" would blight the propaganda effect of the plan of holding 'cascade' accession referenda. 
or three decades. Matters of independence and the process of European integration (joining the EU) are such unique and historically irreversible issues.

Secondly, referenda on such crucial matters (as independence and joining the EU) typically featured high voter turnout and practically unanimous attitudes of voters.

Thirdly, national referenda seem to be well established in the politicallegal systems of Central and Eastern Europe, which is evidenced by the fact that a majority of constitutions directly provide for the procedure of referendum.

Fourthly, Central and Eastern Europe is a region where referenda were relatively frequently held over last twenty years. Although this democratic form of governance was actually born in Western Europe, it has been extensively applied also in Central and Eastern Europe, as evidenced by the fact that all states in this region have held a referendum at least once.

Fifthly, although 'young democracies' (which a definite majority of CEE states are) use referenda to resolve essential matters, it is difficult to talk about a well-established practice of resorting to this instrument, partly owing to negative experiences dating back to before 1989 .

Sixthly, many countries have established turnout thresholds required for a referendum to be valid. ${ }^{15}$ Adopting such provisions means that states face a considerable challenge of ensuring success in referenda, in particular when the issues put to vote are not of symbolic meaning (when turnout tends to be low, making a referendum invalid).

The comparison of the different groups of referenda discussed here in terms of selected features makes it possible to note differences between various types of voting. The most prominent differentiating factor pertains to the subject matter of referenda. Whereas voting on independence and accession to the EU were devoted to a single and precisely formulated issue, the "deepening" referenda addressed a significantly broader range of issues - from the constitution, to the political system, to the withdrawal of Soviet troops, to privatization.

15 Voter turnout at the minimum level of $50 \%$ of those eligible to vote is required in Slovakia, Lithuania, Bulgaria and Romania; when referenda concern the change to the constitution - in Slovenia and Latvia; and in ordinary referenda in Poland. 


\section{Referenda in Central and Eastern Europe - comparison of selected properties}

\begin{tabular}{||l|l|l|l||}
\hline \hline & \multicolumn{1}{|c|}{$\begin{array}{c}\text { Independence } \\
\text { referenda }\end{array}$} & \multicolumn{1}{|c||}{ 'Deepening” referenda } & \multicolumn{1}{|c|}{$\begin{array}{c}\text { Accession } \\
\text { referenda }\end{array}$} \\
\hline Range of topics & $\begin{array}{l}\text { One topic: } \\
\text { independence }\end{array}$ & A broad range of topics & $\begin{array}{l}\text { One topic: acces- } \\
\text { sion to the EU }\end{array}$ \\
\hline Domino effect & Present & Absent & Present \\
\hline Voter turnout & $\begin{array}{l}\text { Very high } \\
\text { (ca. 80\% on average) }\end{array}$ & $\begin{array}{l}\text { Low or relatively low (ca. 50\% } \\
\text { on average) (numerous refe- } \\
\text { renda were invalid) }\end{array}$ & $\begin{array}{l}\text { Relatively high } \\
\text { (ca. 60\% on ave- } \\
\text { rage) }\end{array}$ \\
\hline $\begin{array}{l}\text { Proportion of } \\
\text { 'yes' answers }\end{array}$ & $\begin{array}{l}\text { Very high } \\
\text { (ca. 87\% on average) })\end{array}$ & $\begin{array}{l}\text { Relatively high (ranging from } \\
\text { ca. 38\% to over 90\%) } \\
\text { (ca. 75\% on average) }\end{array}$ & $\begin{array}{l}\text { Very high } \\
\text { (ca. 80\% on ave- } \\
\text { rage) }\end{array}$ \\
\hline Result & $\begin{array}{l}\text { All referenda 'ac- } \\
\text { cepted' }\end{array}$ & $\begin{array}{l}\text { Varied answers, numerous re- } \\
\text { ferenda were invalid }\end{array}$ & $\begin{array}{l}\text { All referenda 'ac- } \\
\text { cepted' }\end{array}$ \\
\hline
\end{tabular}

Source: Own elaboration.

It should be added that, due to the character and significance of the topics of accession and independence referenda, in both types of referenda the effect of their sequential order was taken advantage of. A high proportion of voters supporting independence and accession to the European Union was a result, among other things, of the 'example' set by earlier referenda, as well as of the desire of CEE societies to join the democratic states from Western Europe.

The process of European integration seems to have stimulated the practice of using referenda in the countries of the former Soviet bloc. A similar trend could also be observed in Western Europe. On account of EU membership and progressing integration processes, both groups of states have begun to resort to referenda to a greater extent than before.

This analysis of the practice of holding referenda in CEE states makes it possible to identify three, time-related waves of referenda. The first one took place in the early 1990s, the second fell in the later 1990s, although this was not as clear-cut as the first one, and the third wave could be seen starting in 2003.

On account of the topic of referenda, three types can be identified which overlap with the above-mentioned waves, namely independence referenda (political system transition, beginning of reforms), "deepening" referenda - on the constitution, political system, privatization (deepening and consolidation of changes, further reforms) and accession referenda. 
It has recently become clear that the issues related to the European Union prevailed as the topics of referenda in many states, whether EU members, or those that are not in the EU yet. This suggests that another reason to hold national referenda in some CEE states will be related to the issue of joining the euro zone and adoption of the single European currency.

Summing up, it can be said that the long tradition of holding referenda in European states evidences the fact that it is a significant instrument to empower societies and to create and form civil society (although the experience of CEE states shows that this process may take a long time). This last function of this instrument of direct democracy seems to be of particular importance from the point of view of CEE states.

\section{Bibliography}

Barber B. (1984), Strong Democracy. Participatory Politics for a New Age, Berkley-London.

Budge I. (1996), The New Challenge of Direct Democracy, Polity Press, Cambridge.

Centre for Research on Direct Democracy (c2d), http://www.c2d.ch/.

Cronin T. E. (1989), Direct Democracy. The Politics of Initiative, Referendum, and Recall, Cambridge-Massachusetts-London.

Dziewulski R., Otachel B. (2003), Referenda akcesyjne na Litwie, Stowacji, Czechach, Estonii i Łotwie, "Biuletyn Analiz UKIE", no. 13.

Gebethner S. (2001), Subject Matters of Popular Votes in Eastern and Central Europe, in: Direct Democracy: The Eastern and Central European Experience, eds. A. Auer, M. Butzer, Ashgate Publishing Ltd., Aldershot-Burlington-Singapur-Sydney.

Kaufmann B. (ed.) (2004), Initiative \& Referendum Monitor 2004/2005. The IRI Europe Toolkit for Free and Fair Referenda and Citizens' Initiatives, Amsterdam.

Kishna A. (2001), Enhancing Political Participation in Democracies: What is the Role of Social Capital?, Terry Stanford Institute of Public Policy, Duke, Durham.

Kużelewska E. (2006), Referenda w procesie integracji europejskiej, ASPRA, Warszawa.

Leduc L. (2003), The Politics of Direct Democracy. Referendums in Global Perspective, Broadview Press, Toronto.

Linder W. (1996), Demokracja szwajcarska. Rozwiazywanie konfliktów w spoteczeństwie wielokulturowym, Rzeszów.

Lukšic I., Kurnik A. (2001), Slovenia, in: Direct Democracy: The Eastern and Central European Experience, eds. A. Auer, M. Bützer, Aldershot-BurlingtonSingapur-Sydney. 
Musiał-Karg M. (2012), Doświadczenia wykorzystania instytucji referendum w państwach Europy Środkowej $i$ Wschodniej, in: Stan i perspektywy demokracji bezpośredniej w Polsce, ed. M. Marczewska-Rytko, UMCS, Lublin.

Musiał-Karg M. (2008), Referenda w państwach europejskich. Teoria, praktyka, perspektywy, Wydawnictwo Adam Marszałek, Toruń.

Musiał-Karg M. (2012), Instytucje demokracji bezpośredniej w procesie integracji europejskiej - od referendum ogólnonarodowego do europejskiej inicjatywy obywatelskie, "Rocznik Integracji Europejskiej”, no. 6.

Podolak M. (2014), Instytucja referendum w wybranych państwach Europy Środkowej $i$ Wschodniej (1989-2012), UMCS, Lublin.

Qvortrup M. (2002), A comparative study of referendums. Government by the people, New York.

Rachwał M. (2010), Demokracja bezpośrednia w procesie ksztattowania się społeczeństwa obywatelskiego, Wydawnictwo Sejmowe, Warszawa.

Rytel-Warzocha A. (2011), Referendum ogólnokrajowe w państwach Europy Środkowo-Wschodniej, Wydawnictwo Sejmowe.

Schiller Th. (2003), Direct Democracy in Modern Democratic Evolution, paper presented during International Symposium on Initiatives, Referendums, and Direct Democracy held by The Taiwan Foundation for Democracy (TFD) on October 12, 2003, http://www.tfd.org.tw/english/subject.php?id=en0602.

Suksi M. (1993), Bringing in the People. A Comparison of Constitutional Forms and Practices of the Referendum, Martinus Nijhoff, London.

Ten referenda on Europe in Europe. IRI Europe Referendum Monitoring Report, 2003, IRI Europe, Tartu.

\section{Rola referendum ogólnokrajowego w państwach Europy Środkowo-Wschodniej. Wybrane doświadczenia}

\section{Streszczenie}

Podejmowanie decyzji za pośrednictwem form demokracji bezpośredniej odegrało w Europie Środowej i Wschodniej istotną rolę - szczególnie w latach 89/90, bowiem wyznaczało kierunek dalszego rozwoju państw tamtej części kontynentu. Demokracji bezpośredniej - szczególnie w formie referendum - wzbudza coraz większe zainteresowanie przede wszystkim wśród polityków oraz uprawnionych do głosowania, co uzewnętrznia się m.in. w toczącej się debacie publicznej nad rolą partycypacji obywateli w procesach decyzyjnych, a także we wzroście liczby referendów ogólnokrajowych nie tylko w Europie, ale i na świecie. Stąd podjęcie badań nad instytucją referendum w państw wydaje się być przedsięwzięciem interesującym, ważnym, aktualnym, a przez to wartym naukowej eksploracji. Głównym zamierzeniem badawczym niniejszego tekstu jest odpowiedź na pytanie o rolę instytucji referendum ogólnokrajowego w praktyce politycznej państw Europy Środkowej i Wschodniej 
oraz o perspektywy wykorzystania tej formy sprawowania władzy w przyszłości. Największa uwaga poświęcona została referendom, które przeprowadzono po $1989 \mathrm{r}$. $\mathrm{Na}$ tej podstawie dokonano klasyfikacji na referenda: niepodległościowe, pogłębieniowe i akcesyjne.

Słowa kluczowe: referendum, demokracja bezpośrednia, Europa ŚrodkowoWschodnia 
